the quasi-establishment of Shari'a in limited subject areas, such as the application of family law.

That said, the works in this volume do not really cohere as a collection. Aside from a few brief paragraphs in the introduction, the editors do not offer an interpretive framework, nor, indeed, a concluding chapter. The volume more closely resembles an issue of an academic journal than a thematically coherent set of essays surrounding a common topic. It is unfortunate, because this feature will limit the circulation of this book. A majority of the individual chapters are written by very smart people (many of whose names will be easily recognized by readers of Politics and Religion), who have provided readers with excellent and insightful analyses. I am hopeful that this review, all too brief to do the contributors justice, will provide some guidance for potential readers, who may find individual chapters useful for their own work.

\title{
Muslim Women and Shari'ah Councils: Transcending the Boundaries of Community and Law. By Samia Bano. Basingstoke: Palgrave Macmillan, 2012. 344 pp. $\$ 100.00$ cloth
}

doi:10.1017/S1755048314000339

Christian Joppke

University of Bern, Switzerland

Few issues surrounding Islam in the West provoke more anxiety and polemics than the claim to have Islamic law (Shari'ah) recognized under Western state law. Not only Islamists, but the Archbishop of Canterbury, Rowan Williams, in a headline-making statement to the Royal Courts of Justice in February 2008, found the recognition of socalled Shari'ah Councils in Britain "unavoidable," and he pleaded for a "constructive accommodation" of Shari'ah (quoted in Bano, 274). The tumult generated by his considerate remarks (which referred less to the Koran than to Western elite academics) betrays a deep amnesia in the West about its own tradition of "legal pluralism," which dates back to the medieval age, when Canon (catholic church) law coexisted with various types of secular law, and which Harold Berman found the 
Western legal tradition's "perhaps most distinctive characteristic" and nothing less than a "source of freedom" (Law and Revolution, 10).

Samia Bano's Muslim Women and Shari'ah Councils does a good job of dispelling some of these fears, without denying the conservative bias of the Shari'ah councils that have been operating informally in Britain, unknown to many, for some four decades now, and which are not always good for Muslim women. In her words, "gendered cultural practices are endemic in the councils," relegating Muslim women to the roles of "mothers, wives and daughters" (255). At the same time, it seems to be mostly women, not men, who approach these councils intent on acquiring an Islamic divorce certificate that, while not valid under British law, allows them to save face in their communities and eventually to remarry. Some vividly depicted encounters between young Muslim women, who suffer from oppressive if not violent husbands yet all profess strong Islamic identities that they describe as "empowering," and the traditionalist male "religious scholars" adjudicating their divorce requests, surprisingly often in favor of the women, are well worth reading.

Here is what I learned from this book. Only 190 (3\%) of the 6237 Koran verses contain legal provisions, and most deal with family law and inheritance (80). No wonder that family law, especially divorce certificates, are at the center of the approximately 30 Shari' ah Councils operating in England today, informally and without legal enforcement powers (85). Interestingly, the four Shari'ah Councils (one in Birmingham, three in London) selected by the author for further study all required applicants for divorce with an English civil law marriage to first have acquired a civil divorce - the councils were all at pains not to get into conflict with English law, stressing that divorce certificates were for "personal use" only, "not viewed as legal documents to be recognized under English law," and that there were "no community mechanisms or sanctions in place to enforce the terms of the divorce." Enforcement hinged entirely on the "good will" of the involved parties (141). One does not see here the aggressive pushing back of the secular state that is associated in anti-Islamic demonology with the very word "shari'ah."

Still, there are reasons to worry. The religious scholars interviewed in this book cite as "one of the primary reasons" for women seeking a divorce the "rise of forced marriage," which strangely coincides with the abolition, in 1997, of the much criticized "primary purpose" rule in British immigration law (which invalidated marriages concocted for immigration purposes). Considering that almost $60 \%$ of British South Asian Muslim women in the 19 to 50 age bracket are estimated to have a 
spouse who migrated to Britain to marry (48), the typical constellation before the councils is British Muslim women facing abusive Pakistani spouses, who, like most British Pakistanis, are likely to be Punjabi from the Mirpur region, known for their parochialism (desh pardesh, meaning to build a "home away from home") (5). The study provides insight into oppressive family situations among South Asian Muslims. Certainly, a divorce is in principle possible in Islam (a notably better exit situation than in traditional Catholicism), and the possibility of divorce sits on top of a contractual idea of marriage as nikah that requires the "mutual agreement" of both marriage partners. But the Islamic divorce procedure is heavily biased in favor of the husband, in terms of the talaq that gives men the right to unilaterally terminate a marriage. The divorce cases before the councils are in fact all refusals by men to issue a talaq, which should follow upon an already obtained civil divorce certificate, and without which the woman would be "adulterous" in the eyes of the Muslim community if she married again. This still leaves her with the possibility of a khul divorce. In this "most frequent" divorce request before the councils, the wife must give up her dowry (mahr), and she forfeits any right for future financial support from her divorced husband. This may not be so dramatic, as the average dowry in the cases observed by the author was ridiculously small (between 100 and 200 pounds sterling) (175). However little there was in it for them, strikingly, a copy of the nikah contract had been obtained by only half of the women interviewed by the author. Moreover, less than half of them had their marriage registered under civil law, even if the "majority" of women had wanted a civil registration but "some husbands had simply refused," or they had lied to their wives that their marriage contracts were legally valid, while in reality they were not (161). Accordingly, many a woman appearing before a Shari'ah Council had to find out that she was not even married under English law, making her doubly vulnerable! If one adds that four of the five "dominant reasons" given by women to file a divorce request were "bigamy," "domestic violence," "adultery," and "forced marriage," one must conclude that not all is well with Muslim marriage and family life, which seems to deviate starkly from the West European average.

This study gives a good sense that the accommodation of Islam will have to occur from within Islam, which may include the recognition of Shari'ah councils, but that it will be an arduous process. The experience with the first formal Shari'ah councils, the Muslim Arbitration Tribunals, five of which have been set up since June 2007 under the Arbitration Act of 1996, is not encouraging (the author should have 
explicated the legal and substantive difference between the informal and the more recent, formal Shari'ah Councils a bit more). While still without the power of enforcement and, of course, required to be in line with English law, among the first Muslim Arbitration Tribunals decisions reported in 2007 were the dividing of an estate that awarded double the amount to male than to female heirs (in line with traditional Islamic inheritance rules), and the settling of six cases of domestic violence by husbands by merely requiring them to attend "anger management classes" and "community mentoring," while all six women withdrew their prior complaints to the United Kingdom police (241). On the one hand, there is no reason to deny to Muslims what has been long granted to the Jewish community, in terms of the Jewish rabbinical courts (Beth Din) that have been adjudicating marriage and divorce cases under the British Arbitration Act for many years. On the other hand, the author leaves no doubt that the process is skewed against Muslim women, even if one follows her not small concession that Muslim women may be "agents" yet not beholden to "liberatory politics" (53).

Offering Hospitality: Questioning Christian Approaches to War. By Caron Gentry. Notre Dame: University of Notre Dame Press, 2013. 182 pp. \$29.00 paper. \$20.30 E-book.

doi:10.1017/S1755048314000443

Michael L. Coulter

Grove City College

Caron Gentry's primary contribution to theorizing about international relations in this book is to take the concept of hospitality, as developed in both the Christian tradition and by contemporary postmodern thinkers, and consider how it both challenges and adds to approaches in international relations such as Christian Realism, pacifism, and Just War doctrine. Aiming to engage Christians in the United States in their thinking about power and war, Offering Hospitality is a concise and provocative work.

The first half of the book develops the concept of hospitality as it might relate to foreign affairs: "Expanding hospitality in IR means searching for 